\title{
Imaginar el pueblo / (des)montar la Guerra fría. Apuntes en torno a La rabbia (1963), de Pier Paolo Pasolini
}

\section{Imagining the people / (dis)mounting the Cold war. Notes around La rabbia (1963), by Pier Paolo Pasolini}

\author{
Jaime Vindel Gamonal \\ Universidad Complutense de Madrid
}

Fecha de recepción: 14 de julio de 2017

Fecha de aceptación: 18 de junio de 2018
Anuario del Departamento de Historia y Teoría del Arte vol. 29-30, 2017-2018, pp. 49-65 ISSN: 1130-5517, eISSN: 2530-3562

http://doi.org/10.15366/anuario2017-2018.29-30.02

\section{RESUMEN}

Este artículo rastrea el significado de esta película en el contexto de la cultura italiana de principios de los años sesenta. Para ello, se remonta a la génesis del movimiento antifascista y, más particularmente, del pensamiento de Antonio Gramsci en el período de entreguerras. A continuación, se analiza el modo en que tanto la obra del antropólogo Ernesto de Martino como la trayectoria de Pasolini aparecen tensionadas por su relación con la herencia gramsciana. Más adelante, se desmenuza la comprensión histórica de La rabbia en diálogo con los conceptos de "imagen dialéctica" (Walter Benjamin) y "gesto" (Giorgio Agamben), subrayando el modo en que ambos encarnan en la película de Pasolini una fractura con la idea gramsciana del marxismo como reforma moral moderna. Finalmente, esos argumentos son relacionados con la aproximación a las culturas campesinas desde una política del pianto rebelde, en el cruce entre los estudios antropológicos de De Martino, la poética de Pasolini y la construcción de una semiótica cinematográfica de la subalternidad.

\section{PALABRAS CLAVE}

Gramsci. De Martino. Pasolini. La rabbia. Imagen dialéctica. Gesto. Pianto.

\begin{abstract}
This article traces the meaning of this film in the context of the Italian culture at the beginning of the sixties. To do so, it briefly returns to the genesis of anti-fascism movement and, more particularly, of the thought of Antonio Gramsci in the interwar period. Then, it analyzes the way in which both the work of the anthropologist Ernesto de Martino and the trajectory of Pasolini are stressed by their relationship with the Gramscian legacy. Later, it explains in detail the historical understanding of La rabbia in dialogue with the concepts of "dialectical image" (Walter Benjamin) and "gesture" (Giorgio Agamben), highlighting the way in which both materialise in the Pasolini film the fracture with the Gramscian idea of Marxism as a modern moral reform. Finally, those arguments are related to the approach to the peasant cultures through the politics of the rebellious pianto, crossing the anthropological studies of De Martino, the poetics of Pasolini and the construction of a film semiotics of the subalternity.
\end{abstract}

\section{KEY WORDS}

Gramsci. De Martino. Pasolini. La rabbia. Dialectical image. Gesture. Pianto. 


\section{Gramsci- De Martino- Pasolini: antifascismo, marxismo e historia en Italia después de la Segunda guerra mundial ${ }^{1}$}

La constitución del antifascismo durante los años treinta del siglo XX generó un ethos colectivo cuyo alcance como movimiento internacional aglutinaba una doble dimensión política y cultural. Según los casos, el énfasis en la ética característico de esa esfera pública transnacional se contraponía a/complementaba la descarnada conciencia del marxismo sobre la base economicista de los procesos históricos, amparada por la famosa contradicción estructural entre el desarrollo de las fuerzas productivas y las relaciones de producción. Podemos considerar como una bisagra entre esas dos cosmovisiones la obra de Antonio Gramsci, cuyo acento cultural inauguraría una variante del marxismo que ha impregnado la historia intelectual de la izquierda occidental desde entonces hasta hoy.

Sin embargo, en un inicio la cultura del antifascismo no se encontraba ceñida al campo comunista. Como ha subrayado Enzo Traverso, la emergencia del antifascismo se vinculó a la cultura del exilio italiano, particularmente activa en Francia y Estados Unidos desde 1925. Fue de hecho Benedetto Croce -un pensador inscrito en la tradición idealista y cuya ascendencia intelectual alcanzaría al propio Gramsciquien instigó en ese año la publicación en el diario Il Mondo de un manifiesto que se suele identificar con el germen del movimiento, cuyas concentraciones en el espacio público aunarían a un amplio espectro de sensibilidades ideológicas, desde socialistas a republicanos. Los comunistas fueron, paradójicamente, quienes más tardíamente se integraron en esa esfera colectiva: lo hicieron tan solo en 1935, dos años después de la llegada de Adolf Hitler al poder, cuando tras abandonar la denuncia del social-fascismo socialdemócrata, adoptaron la consigna del Frente Popular.

Traverso subraya que esa unión temporal fue posible por la gravitación negativa de todas esas sensibilidades en torno a las consecuencias de la irrupción del fascismo en la política internacional. Más allá de ese aspecto nuclear, el espacio compartía una defensa del progreso ilustrado como antítesis del irracionalismo vitalista y antihumanista del totalitarismo. En ella, el nazismo aparecía como la encarnación de una política arcaica, una cosmovisión que minusvaloraba sus aspectos específicamente modernos, desde la instrumentalización aclamativa de las masas a la aplicación genocida de la técnica, lo que ayuda a explicar el modo en que numerosos intelectuales antifascistas pasaron de puntillas sobre la memoria inmediata del Holocausto. Serían la Guerra civil española y la trama relacional de la cultura de la Resistencia las que articularían la red de afectos del antifascismo, cuya disolución coincidió con la de la amenaza que la había fraguado $^{2}$. Con el ocaso del fascismo histórico, esa "religión civil" de la democracia y el socialismo solo perviviría en el país de Europa occidental donde la presencia del poder totalitario se había prolongado durante más tiempo y con especial intensidad: Italia. Tanto la Democracia Cristiana como el Partido Comunista se reconocerían en un universo de sentido que, ante la flaqueza del liberalismo en los años treinta, los comunistas habían sabido hegemonizar en el plano cultural y político.

La habilidad de la operación gramsciana consistió en integrar los referentes clásicos de la alta cultura italiana (tamizados por la mirada de Croce) y la aproximación a la cultura popular del mezzogiorno con una renovación del marxismo que situaba en el centro del discurso la cuestión de la subjetividad. El interés

\footnotetext{
1 Este trabajo ha sido realizado gracias a la concesión de la Ayuda Juan de la Cierva - Incorporación 2015 del MICINN y como parte de los proyectos de investigación en los que participa el autor: "Visualidades críticas: reescritura de las narrativas a través de las imágenes" (HAR2013-43016-P, Ministerio de Economía y Competitividad del Gobierno de España) y "Modernidade(s) descentralizada(s): arte, política y contracultura en el eje trasatlántico durante la Guerra Fría" (HAR2014-53834P, Ministerio de Economía y Competitividad del Gobierno de España).

2 Enzo Traverso, A sangre y fuego. De la guerra civil europea (1914-1945), Valencia, Universitat de València, 2009 [2007], pp. 209-223. Además del final de la Segunda guerra mundial, fueron decisivos en la fragmentación del antifascismo la división de Alemania en 1949 (que cimentaba la política de bloques de la Guerra fría) y la represión de la insurrección húngara en 1956 por las tropas soviéticas (que detonó una crisis irresoluble en el movimiento comunista internacional).
} 
por el folclore de Gramsci no debe entenderse, sin embargo, al margen de su conciencia historicista de la modernidad, bastante próxima en este sentido a la fe progresiva de la cultura antifascista. Antes que otorgar a las culturas subalternas un valor en sí mismas, Gramsci pensaba que la "filosofía de la praxis" -el término bajo el que camuflaba la alusión al marxismo en los Cuadernos de la cárcel (1929-1935)- debía cumplir una misión histórica precisa: implementar aquella reforma moral que permitiera superar el "materialismo metafísico" de la cultura popular. Para el pensador sardo, si ese materialismo no encontraba la forma moderna (histórica) que lo extrajera de su atemporalidad consuetudinaria, se vería cooptado más temprano que tarde por las relaciones de hegemonía cultural y dependencia económica impuestas por la clase dominante. Esta misión se tornaba aún más urgente en una nación que, antes y después de su constitución, no había sido unificada a nivel cultural ni por la contrarreforma católica, ni por la monarquía borbónica ni por la revolución burguesa.

Este planteamiento ponía en una tesitura sumamente delicada a quienes, como el antropólogo Ernesto de Martino, abogaban por implementar una etnografía materialista que rescatara del olvido de la Historia a esas realidades culturales otras. Imbuidos de la huella gramsciana y sometidos aún al mito de la URSS como patria y vanguardia mundial de la clase obrera, los escritos de los años cuarenta de De Martino acusaban a la etnología funcionalista de deshistorizar el estudio de las comunidades humanas. Los herederos de Malinowski habrían colaborado así con las formas de gobernanza colonial, que al cercar esas poblaciones en entornos de excepción aseguraban la supremacía de las elites metropolitanas. De Martino argumentaba que tal posición epistémica y política se tornaba insostenible en el contexto de la irrupción en la Historia de esos pueblos, que en las décadas siguientes daría lugar a los procesos de liberación nacional en África y otras partes del mundo. Sin embargo, el antropólogo se mostraba por entonces mucho menos proclive a cuestionar el carácter monolítico de la Historia, desmereciendo la pluralidad irreductible de temporalidades que atraviesan la cartografía de lo que hemos dado en llamar modernidad. A la vez que se felicitaba de la emergencia del Tercer mundo en la agenda política internacional, la especificidad de esas culturas era subsumida al interpretarse como epifenómeno de la revolución comunista mundial iniciada por el Octubre soviético. Sin ánimo de negar la relación entre la existencia de la URSS y la eclosión de esos procesos de liberación, este gesto ideológico generaba un efecto profundamente distorsionador. En última instancia, para De Martino la benigna desnaturalización de la comprensión etnológica de la vida de esas comunidades (su historización), había tenido su correlato histórico tumoral en los efectos barbarizantes sobre la cultura progresiva ocasionados por el asalto plebeyo a la Historia. Ante esa circunstancia, el faro iluminador debía seguir siendo la URSS ${ }^{3}$.

Esta situación hacía tan oportuna como acuciante la recomposición del proyecto gramsciano, que debía trasponer al ámbito italiano la "mundanización del pensamiento" impulsada por el estado obrero eurasiático. El folclore, por tanto, debía ser instrumentado políticamente en sentido progresivo. De Martino redundaba en la atribución gramsciana de un carácter inorgánico a la cultura popular ${ }^{4}$. El partido como intelectual orgánico debía actuar como el príncipe moderno capaz de cabalgar un movimiento nacional y popular construido desde abajo (la Resistencia y el antifascismo) y que, por primera vez en la historia italiana, estaba en disposición de integrar la cultura popular en un orden nuevo. Esa síntesis más avanzada debía desprender al folclore de su identificación romántica y subyugada con el imaginario nacional. Si esta había sido una adscripción simbólica propiciada por la burguesía decimonónica, el nuevo Estado debía asentarse sobre bases ideológicas de signo racionalista, laico y civil.

\footnotetext{
3 Ernesto De Martino, El folclore progresivo y otros ensayos, Barcelona, MACBA, 2008. Especialmente, los artículos "Cultura y clase obrera", publicado originalmente en Quarto Stato, III, n 1 (1948), "En torno a una historia del mundo popular subalterno", publicado originalmente en Societá, V, n 3 (1949) y "Gramsci y el folclore", publicado originalmente en Il Calendario del Popolo, $\mathrm{n}^{\circ} 8$ (1952).

${ }^{4}$ Los calificativos empleados eran "fragmentaria, disgregada, contradictoria, caóticamente estratificada, anacrónica o ideológicamente servil”, ibidem, pp. 111-114.
} 
Al margen de los aspectos teológicos de este historicismo, su vigencia solo pudo sostenerse en un contexto en que la URSS aún mantenía intacto el prestigio de su brújula histórica y donde la cultura antifascista prometía acabar con la secular fragmentación del Estado italiano. La llegada de los años cincuenta, con el derrumbe de la figura de Stalin, la crisis del movimiento comunista internacional (especialmente tras los acontecimientos de Hungría en 1956) y la aparición de grietas en el bloque marmóreo del antifascismo, harían que este proyecto se tambaleara de modo definitivo. Ello desdibujaría los perfiles de su vocación revolucionaria, al tiempo que favorecería una aproximación a la cultura popular que ya no requería medir su validez en relación ni a la reforma civil que el marxismo había proyectado ni a los esquemas ideológicos del romanticismo burgués. Es en la segunda mitad de esa década cuando Pier Paolo Pasolini escribe Le cenere di Gramsci (1957) y De Martino publica Morte e pianto rituale nel mondo antico: del lamento pagano al pianto di Maria (1958), donde recopilaba sus investigaciones etnográficas en la comarca de la Lucania italiana. Al fin los restos del antifascismo marxista podían enfrentarse con la cultura popular como una forma alternativa de lidiar con la vida y la muerte, sin necesidad de identificar en ella una expresión de irracionalidad a trascender à la Hegel -como había sucedido antes-o destinada a quedar confinada irremediablemente en las redes del consumo kitsch - como sucedería después. En las páginas que siguen trato de dilucidar cómo esa oportunidad fue aprehendida por La rabbia, la película que Pasolini realizó entre 1962 y 1963, con la intención de constelar a partir de ella una interpretación sintomática del período. Para esta aproximación, me serviré de los conceptos de "imagen dialéctica" (Walter Benjamin) y "gesto" (Giorgio Agamben), subrayando el modo en que ambos ayudan a pensar la relación entre las imágenes y la crítica del progreso.

\section{La rabbia: hacia una geología dialéctica de las pasiones}

El proyecto para la realización de La rabbia partió de una propuesta de Gastone Ferranti, vinculado a la productora de cinegiornali (noticieros cinematográficos) Astra Cinematografica e Opus Film. La intención de Ferranti era componer un film a episodi (película por episodios) que incluyera un cortometraje de Pasolini junto al de otros siete directores. Para entonces (1962), el poeta italiano había estrenado ya Accattone (1961) y se encontraba inmerso en la presentación de su segunda película, Mamma Roma, que se proyectaría en el festival de Venecia de ese año. Pasolini convenció en un primer instante a Ferranti para descartar esa opción y respaldarle en un proyecto orientado a realizar una política de montaje concebida como un "ensayo de periodismo cinematográfico"5. Para ello, Pasolini partió de una serie de materiales de archivo procedentes del semanario de actualidad Mondo libero (1951-59), cuyo perfil ideológico resultaba antitético en relación al que el cineasta deseaba otorgar a la película. Entre los más de 90.000 metros de película visionados, repletos de "cosas sórdidas" y muestras del "triunfo de la reacción más banal" en la lucha ideológica de la posguerra, Pasolini rescató aquellos fragmentos que por su "expresividad figurativa" ("la sonrisa de un desconocido, dos ojos con una expresión de alegría y de dolor") o por su "significado histórico" emergían como resplandores de vida en un blanco y negro "muy fascinante desde el punto de vista visual". Partiendo de este pie forzado, Pasolini se propuso construir un montaje de imágenes y textos con la voluntad de "inventar un nuevo género cinematográfico", que adquiriría los rasgos de un "ensayo ideológico y poético"6. Pasolini actualizaba así la imagen benjaminiana del trapero de la historia, una metodología de trabajo que, sin embargo, lo alejaba de un contacto más directo con la realidad de las clases subalternas, motivo por el cual abandonaría más tarde esta veta. El montaje original de la película fue

\footnotetext{
5 De este modo la describía el propio Pasolini en una entrevista concedida a la RAI el 3 de septiembre de 1962, cf. Roberto CHIESI, 'Il 'corpo' tormentato di La rabbia. La genesi del progetto, la 'normalizzazione' del 1963, l'ipotesi di ricostruzione del 2008”, Studi pasoliniani. Rivista Internazionale, no 2 (2009), p. 14.

6 Ibidem, p. 16.
} 
cortado cuando se obligó al cineasta a compartir el metraje con una propuesta antagónica a la suya en el estilo y la ideología. Durante la primavera de 1963, el film se exhibiría por un periodo muy breve de tiempo en las salas de cine en diálogo con la aportación del cómico derechista Giovanni Guareschi. Esta imposición, que hizo que el poeta italiano decidiera retirar su firma de la obra final, pudo deberse al deseo de Ferranti de salvar la censura, que previsiblemente se abalanzaría contra la apoteosis comunista del final de La rabbia, con el recibimiento triunfal del astronauta Titov en la Plaza Roja ${ }^{7}$.

La cineteca de Bolonia impulsó en el año 2008 una reconstrucción de la estructura original de la película, supervisada por Roberto Chiesi y realizada por Giuseppe Bertolucci ${ }^{8}$. La primera secuencia del filme (ausente en la copia difundida en los sesenta) correspondía en el guión de Pasolini a los funerales de Alcide de Gasperi (1954), estatista democristiano y uno de los padres del proyecto europeo. Su muerte se relacionaba con el final de las pasiones civiles del antifascismo y el inicio de una época de "normalización" contra la que se revolvía el experimento visual de Pasolini. Frente al orden cronológico, el poeta italiano inspiraba un orden poético-político de las imágenes y los acontecimientos (de las imágenes como acontecimientos visuales) que diagramaba los resortes del film-ensayo, una forma de "pensar a través de las imágenes" en la que ya se habían adentrado previamente cineastas como Chris Marker (Lettre de Sibérie, 1957) .

La naturaleza anfibia de la película respondía a un umbral ideológico y temporal en la trayectoria de Pasolini. La crítica de la modernidad que presagiaba la tonalidad descarnada de los escritos luteranos y corsarios se conjugaba en La rabbia con la esperanza que la URSS postestalinista representaba para el destino emancipado de la humanidad. El progreso científico escenificado distópicamente por el hongo nuclear, encontraba su contracara afirmativa en los logros soviéticos en la carrera espacial. El filme anunciaba una temática recurrente en toda la producción posterior pasoliniana: la homologación subjetiva derivada de la generalización de la industria cultural y la sociedad de consumo neocapitalistas. Pero era ante todo una elegía redentora de los signos visuales de resistencia que aún emergían en los rostros de la subalternidad global, una contestación a la amenaza de nuevas formas de alienación, cuyo éxito final haría que Pasolini abjurara en los setenta de su Trilogía de la vida ${ }^{10}$.

La rabbia fue su particular elogio de "los condenados de la tierra" dir del carácter instrumental de la teoría del montaje intelectual, en el que la sucesión de imágenes perseguía inducir en el espectador la asunción de ideas/ conceptos previamente establecidos por el director, para dar forma a lo que denominaré una "geología dialéctica de las pasiones". En tanto índice de lo que sería una constante de la obra pasoliniana, La rabbia se planteaba como una crítica del logocentrismo occidental, asociado con la imagen del poder. El constante contrapunto entre las diversas voces e imágenes trataba de generar un exceso poético que desbordara el significado del molde de los discursos oficiales. La relevancia que adquirían los gestos y los rostros hacía emerger, frente a la sucesión inexorable del tiempo cronológico en que se basa la visión progresiva de la Historia, una serie de supervivencias expresivas (Nachleben) que anacronizaban la percepción del presente. Esas supervivencias han sido asociadas a las fórmulas del pathos (Pathosformeln) analizadas por Aby Warburg. Sin embargo, en estos apuntes sobre la propuesta pasoliniana, me interesa más aproximarla a otro concepto warburgiano, que Georges Didi-

\footnotetext{
${ }^{7}$ Los materiales soviéticos incluidos en la película se debieron al trabajo en diferentes archivos de la URSS e Italia de Carlo di Carlo, quien ya había colaborado como ayudante de dirección de Pasolini en sus primeras películas. A las imágenes de repertorio se añadieron una serie de reproducciones de pinturas y fotografías.

8 Roberto CHIESI (coord.), Pier Paolo Pasolini. La rabbia, Bolonia, Cineteca di Bologna, 2009.

9 Laura Rascaroli ha explorado recientemente la constitución del cine-ensayo como una forma de pensar a través de las imágenes, cf. Laura RAsCARoli, How the essay film thinks, Oxford, Oxford University Press, 2017.

${ }^{10}$ La trilogía se compondría de las películas El Decamerón (1971), Los cuentos de Canterbury (1972) y Las mil y una noches (1974).

11 El libro homónimo de Frantz Fanon se había publicado, con prefacio de Jean Paul Sartre, en 1961.
} 
Huberman ha puesto en relación con la sintomatología temporal freudiana. Me refiero a la comprensión de las imágenes como fósiles en movimiento (Leitfossil):

Freud, en realidad, plantea la Zeitlosigkeit [intemporalidad] del inconsciente como una condición dialéctica -la negatividad fecunda- del propio flujo temporal. Porque bajo el río del devenir está también el lecho del río: es decir, el otro tiempo del flujo. Son bloques desprendidos de las montañas, piedras trituradas, sedimentos, improntas geológicas, arenas movidas por un ritmo completamente diferente al que pasa por encima. Existe, pues, bajo la cronología del río que corre a través de las gargantas del lecho (...), su condición crónica, cuyos accidentes, invisibles en superficie, determinarán las zonas de torbellinos, los anacronismos de la corriente que se bifurca de repente o se vuelve sobre sí misma ${ }^{12}$.

La negatividad fecunda del gesto subalterno aparecería en La rabbia con la cualidad sensible de aquellos fósiles del légamo de la historia, que aún albergarían la fuerza expresiva para alterar el decurso de su corriente: lo crónico que surge de modo anacrónico en lo cronológico. Frente a las presunciones idealistas del Espíritu Absoluto y su despliegue universal, una de las principales aportaciones del materialismo histórico ha sido la comprensión de las formaciones y conflictos sociales como procesos de larga duración, en los que la materialidad concreta de los modos de producción (que incluye la interacción entre el desarrollo de las fuerzas productivas, las relaciones de producción, los dispositivos normativos y los hábitos de la vida social) impone una serie de límites y persistencias al cambio histórico. Incluso al atender a los factores subjetivos de la lucha de clases, ese materialismo no dejó de subrayar que en los ciclos prolongados la dialéctica social adopta más bien la temporalidad friccional de la tectónica de placas. Sin embargo, en su evaluación de la geología histórica ha tendido a desconsiderar las pasiones humanas, la dimensión activa de esa tenacidad rocosa sin la cual es imposible comprender los seísmos históricos a los que damos el nombre de acontecimientos. Esa prospección es la que Pasolini trataba de poner en imágenes.

Uno de los momentos culminantes de La rabbia son los fragmentos de un reportaje de los funerales que siguieron a la tragedia minera de Morgnano (Peruggia), donde durante la noche del 22 de marzo de 1955 murieron veintitrés trabajadores como consecuencia de una explosión. Pasolini había admirado en alguna ocasión el arrojo de los mineros, tras compartir con ellos la experiencia de bajar a las profundidades de la tierra $^{13}$. El lamento por su desaparición constituía en los rostros de las mujeres la "clase del pianto", el anuncio de una comunidad del duelo: "Es la clase de los chales negros de lana, de las batas negras de pocas liras, de los pañuelos que envuelven las caras blancas de las hermanas, la clase de los gritos antiguos, de las cristianas esperas, de los silencios fraternos del barro y de la grisura de los días del llanto, la clase que da supremo valor a sus pobres mil liras, y sobre esto, apenas funda una vida capaz de iluminar la fatalidad del morir”. ¿De dónde procedía esta articulación alegórica entre la geología, la clase, el llanto, lo arcaico, la pobreza y la muerte?

En uno de los pasajes de la película, la voz poética de Giorgio Bassani afirma: "la tradición es una grandeza que se puede expresar en un gesto (...); a través de los siglos ha devenido puro como el vuelo de un pájaro, elemental como el movimiento de una ola. Pero solo la Revolución salva el Pasado". Estas palabras se sobreponen sobre una secuencia en la que se suceden la imagen de Lenin procedente de la película de Sergej Jutkevich Rasskazy o Lenin (de 1955, con Maksim Schtrauch encarnando al dirigente soviético) y un fragmento de danza de la bailarina Galina Ul'anova en el Teatro Bolshoi. Dos apuntes: el primero tiene que ver con la relación temporal que pasado y revolución mantienen en Pasolini. Para el poeta italiano, la Revolución es aquel acontecimiento que hace irrumpir el pasado bajo una forma emancipatoria

12 Georges Didi-huberman, La imagen superviviente. Historia del arte y tiempo de los fantasmas según Aby Warburg, Madrid, Abada, 2009 [2002], p. 289.

13 Este pasaje de la obra pasoliniana es el punto de partida de la aproximación a La rabbia propuesta por Georges DidiHuberman en G. Didi-Huberman, Sentir le grisou, París, Les Éditions de Minuit, 2014. 
que fractura el diacronismo de la Historia. Es en este sentido que podemos comprender la paradoja de los versos leídos por Orson Welles en La ricotta (también de 1963) y reproducidos en Poema en forma de Rosa (1964), cuando al declarar su amor por la tradición, Pasolini se identificaba con "una fuerza del pasado" que, sin embargo, le hacía "más moderno que cualquier moderno". En este punto la proximidad de Pasolini a Walter Benjamin resulta notable, así como el alejamiento que esta poética del gesto evidencia en relación al historicismo de Gramsci. La singularidad de Benjamin en la tradición marxista consiste en haber sabido conjugar de manera singular (y no exenta de las contradicciones de un tiempo tumultuoso), el determinismo tecnológico del proyecto productivista con el mesianismo antihistoricista de la imagen dialéctica. Si las tesis Sobre el concepto de historia (en particular, la VIII y la XII) estaban escritas tanto contra el fascismo como contra la socialdemocracia, La rabbia es una expresión avanzada de la "furia" que Pasolini vertía contra el nuevo fascismo neocapitalista (más efectivo que el histórico, en la medida en que borraba todo rastro de conciencia interior disidente), pero también (y esto suele pasar inadvertido) una muestra de la inadecuación entre la sensibilidad de su autor y la vía italiana al socialismo, signada por la política reformista del PCI, que sería más tarde tildada de socialdemócrata por la izquierda operaísta -la cual, por otra parte, nunca mantuvo una relación exenta de conflictos con el propio Pasolini.

Tanto para Benjamin como para Pasolini la perspectiva del progreso histórico era insostenible desde la posición de la subalternidad. Pero el cineasta italiano iba más allá: si la cultura del antifascismo se había caracterizado por su defensa de la racionalidad ilustrada frente al irracionalismo vitalista de las formas arcaicas de la cultura, Pasolini parecía retomar el impulso benjaminiano de retornar sobre la cuestión del origen al margen de sus connotaciones esencialistas, racistas o filogenéticas. Por formularlo nuevamente de manera sintética: frente al desdén del antifascismo por el origen como un resto arcaico, se trataba de arrebatar el concepto de las garras del fascismo. Del mismo modo que Didi-Huberman ha identificado en Benjamin una concepción del "origen-torbellino" opuesta al "origen-fuente"14, esa misma figura puede rastrearse en proyectos como el que Pasolini dejó inacabado cuando fue asesinado en noviembre de 1975. Petrolio compilaba los resultados de una aventura de investigación política y poética en la que describía la conversión de la ENI (la empresa estatal de hidrocarburos, con una sólida presencia en el imaginario popular como símbolo de la economía nacional) en un ente abierto a la globalización neoliberal, que sepultaba la herencia antifascista de la gestión de Enrico Mattei. Pasolini se refería a la estructura "hormigueante" de ese relato como la "forma de un remolino"15. Tal modo de concebir la relación entre texto e imagen perseguía, por otra parte, deshacer el "estado de excepción" como regla (Benjamin) o el estado de normalidad al que Pasolini aludía en un escrito que abocetaba los propósitos de La rabbia ("Il trattamento", 1962) ${ }^{16}$. Contra esa normalidad, el cineasta pensaba que correspondía a los poetas ("campeones de la rabia intelectual, de la furia filosófica") la labor de crear artificialmente un "estado de emergencia", que recuerda de inmediato al "estado verdadero de excepción" que Benjamin reclamara en la lucha contra el fascismo.

El segundo apunte que deseo realizar sitúa a Pasolini como una sensibilidad puente entre la obra de Benjamin y la de Giorgio Agamben. En La rabbia, el gesto de los subalternos, al socavar la relación instrumental entre discurso, imagen y poder, anuncia la comprensión de aquel como "pura medialidad" en los escritos de Agamben ${ }^{17}$. Al no someterse a la relación entre medios y fines, el gesto sería aquello que libera a la imagen del poder, su irrupción sensible como acontecimiento. En una línea que preludia la crítica debordiana de la sociedad del espectáculo, la imagen-acontecimiento aparece entonces como aquella entidad visual que, a través del montaje, se opone a la anarquía del poder espectacular -en un doble sentido,

\footnotetext{
14 Georges Didi-Huberman, Ante el tiempo. Historia del arte y anacronismo de las imágenes, Buenos Aires, Adriana Hidalgo, 2008 [2000], pp. 101-129.

15 Pier Paolo Pasolini, Petróleo, Barcelona, Seix Barral, 1993 [1992], pp. 104 y 111.

16 CHIESI, 2009, pp. 13-14.

17 Giorgio Agamben, Medios sin fin. Notas sobre política, Valencia, Pre-Textos, 2001 [1996], pp. 47-86.
} 
por su arbitrariedad y por su falta de fundamento ${ }^{18}$, al tiempo que deshace su orden (arché) del discurso. Pero La rabbia iba nuevamente más allá: en la imagen altermundista de lo popular que compone Pasolini, el logocentrismo queda asociado con el sujeto moderno occidental. El cineasta italiano avanzaba así una respuesta a la pregunta de Gayatri Spivak sobre si pueden hablar los subalternos: el gesto era la parole que el pueblo estaba en disposición de oponer a la langue del poder en la dialéctica histórica de la Guerra fría. El variopinto proletariado (multirracial y transnacional) que La rabbia intentaba reconstruir aparecía recortado contra el trasfondo de un contexto cultural europeo signado por la desaparición de los gestos en la burguesía occidental, un hecho que Agamben establecía a finales del siglo XIX. Antes de constatar con desgarro el genocidio que la industria cultural perpetraría sobre cualquier forma de resistencia subjetiva (la famosa desaparición de las luciérnagas), Pasolini diagramaba un ejercicio expresivo que no renunciaba a intercalarse en el espacio semiótico definido por aquella. Frente al énfasis de diversas ramas del saber occidental (sociología, filosofía analítica, psicoanálisis, estructuralismo) en la semiótica significante del lenguaje, La rabbia exploraba lo que Félix Guattari denominó la semiótica simbólica (la fisicidad y expresividad del cuerpo), cuyo campo empezaba a ser central en las formas de producción de subjetividad de la industria cultural.

La evocación de la grandeza gestual de la tradición se superponía en La rabbia sobre el movimiento corporal de la bailarina Ul'anova. Justamente en la danza se haya, como ha señalado Agamben, el gesto como soporte y exhibición del "carácter de medios de los movimientos corporales": "El gesto es la exhibición de una medialidad, el hacer visible un medio como tal"19. Esa pura medialidad, en la medida en que es ajena a la relación instrumental entre medios y fines de las visiones progresivas de la Historia, habilitaría la posibilidad de practicar en ella un corte del que emergiera el estado de excepción verdadero ansiado por Benjamin y Pasolini contra la normalidad del (pos)fascismo. El carácter preverbal de la semiótica simbólica se correspondía, por otra parte, con la defensa pasoliniana del cine de poesía como lenguaje de la acción. El cine se componía para Pasolini de una serie de "im-signos" pregramaticales que lo hacían aparecer como un Ur-código o lenguaje del origen: el de la praxis vital o la interacción humana con su medio de vida. El cine, más que configurar técnicamente nuestra percepción de la realidad, revelaría ante nuestros ojos la materialidad concreta de la experiencia perceptiva que hacemos del mundo, la cual de otro modo pasaría desapercibida. Así conjugaba Pasolini técnica y naturalismo ${ }^{20}$.

La imagen rabiosa es, por tanto, una imagen desencadenada, que desmonta los imaginarios de la Guerra fría (los cinegiornali que constituyeron el material de partida del proyecto), remonta a contrapelo su sentido histórico y, para concluir, monta una nueva constelación sensible. Exponer los pueblos consiste entonces en mostrar su sobrevivencia como un síntoma de resistencia ${ }^{21}$. Podríamos afirmar que, en este plano, La rabbia actúa como un anti-dispositivo de la soberanía visual contemporánea: la imagen dialéctica en Benjamin y los im-signos en Pasolini instigarían la anarquía que la tradición de los oprimidos está en disposición de oponer a la anarquía que habita en el corazón mismo del poder. Pero la "furia filosófica" que diagrama La rabbia se inscribe también en la concepción de los stracci (la expresión, empleada por el propio Pasolini, significa literalmente "trapos" o "retales", lo que la acerca de forma evidente a la imagen dialéctica en Benjamin) cinematográficos como imágenes del sueño. Marco Antonio Bazzochi ha resaltado, en este punto, la proximidad entre el concepto de montaje de la película de Pasolini y los inicios de la

18 "La anarquía es lo que el gobierno debe pre-suponer y asumir como el origen del que procede y, a la vez, como la meta que orienta su viaje. (Benjamin tenía razón en este sentido cuando escribía que no hay nada tan anárquico como el orden burgués; y la ocurrencia que Pasolini hace proferir a uno de los jerarcas de la película Salò, 'la única anarquía verdadera es la del poder', es totalmente seria)", Giorgio AgAmBen, El reino y la gloria. Por una genealogía teológica de la economía y del gobierno, Valencia, Pre-Textos, 2008 [2007], p. 80.

19 Agamben, 2001, p. 54.

20 Pier Paolo Pasolini, Empirismo herético, Córdoba, Editorial Brujas, 2005 [1993]. En particular, "La lengua escrita de la realidad", escrito en 1966 (pp. 273-308) y “El código de los códigos”, de 1967 (pp. 373-380). 
historia del cine, convocando una metáfora en la que los estratos geológicos del Leitfossil y los surcos oníricos de la imagen parecen coincidir:

Pasolini, siguiendo el modelo del cine de los orígenes (...), no esconde discontinuidades, elipsis, pasajes. Cuando Pasolini teoriza el cine de poesía, dice explícitamente que bajo cada película "en prosa" discurre un segundo film "en poesía", bajo la narración discurre un mundo onírico, irracional, que sin embargo requiere de la narración para poder ser captado. Este film subterráneo y onírico nosotros no lo vemos, pero lo sentimos: a través de las relaciones internas, los reclamos de los encuadres, el montaje. Y reconstruyendo el film subterráneo entramos en un mundo distinto del nuestro, diverso no solo antropológicamente ${ }^{22}$.

El rescate del mutismo originario del cine devolvería la imagen (y los cuerpos) de los olvidados de la Historia a la patria común, múltiple e internacionalista del gesto (Agamben). Para ello, Pasolini se sirve de una serie de recursos estilísticos concretos: 1) la estructura-torbellino del film, que responde a una sucesión de appunti ${ }^{23}$, stracci y ritornelli; 2) la fuerza poética derivada del contrapunto y la multiplicidad de imágenes y voces: informativas (la voz oficial del noticiero), narrativas (la voz crítica de Renato Guttuso) y poéticas (el canto épico-elegíaco de Bassani, en el que se cifra el arcaísmo y la sobrevivencia del pianto fúnebre, con su promesa de reconciliación cósmica y fraterna, de matriz antropológica); 3) la factografía, es decir, la (re)escritura de los hechos que Pasolini asume al afirmar que su trabajo se adscribe antes a la labor periodística que a la de un artista.

Desde esta perspectiva, los referentes a los que se remonta la "rabia pasoliniana" son múltiples, pero parece afín a una versión cinematográfica de la furia melancólica de los epigramas del Kriegsfibel (ABC de la guerra), que Bertolt Brecht diagramara entre 1940 y 1945. Tanto allí como en La rabbia, la elegía poética interpelaba a la información descriptiva y a los registros visuales de modo que el montaje de imágenes-textos se ubicara más allá de la estructura cognitiva del documental. En el caso de Pasolini, se trataba en última instancia de situar la lucha de clases en el corazón de la belleza. En este sentido, la secuencia dedicada a Marilyn Monroe parecía redimir a la subalternidad del destino fatal de la guerra y la bomba nuclear. El lamento fúnebre se compone allí con el recuerdo pletórico de la imagen de la actriz. Su inocencia aurática emerge como reducto sensible contra una burguesía que, alienada de la naturaleza y de la historia, veda el acceso a sus tesoros culturales al proletariado.

Por otra parte, La rabbia muestra una comprensión alegórica de la mímesis que nos retrotrae a la literatura de Dante y Petrarca. Patrick Boucheron ha señalado esa misma ascendencia en la "chanson politique" que atraviesa los frescos del Buen y el Mal Gobierno del Palazzo Pubblico de Siena, pintados por Ambrogio Lorenzetti en $1338^{24}$. En ambos casos, la reproducción de la realidad se construye como una articulación alegórica de las imágenes y los textos cuya capacidad de persuasión sintetiza la alusión intelectual a un marco cultural de referencia y a una dialéctica afectiva de las pasiones. La posibilidad de trascender la oposición entre realismo y alegoría vendría dada, en opinión de Boucheron, porque el concepto de semejanza (ressemblance) que opera en la tradición petrarquista no piensa esta como una adecuación entre la representación y el mundo, sino como un efecto derivado de la comparación de dos realidades con un "aire" común, pero que comprende también sus diferencias. Tanto en Siena como en La rabbia, ese efecto sería inducido a su vez por la superposición de los textos sobre las imágenes, que lejos de fijar de modo unívoco el sentido de estas últimas contribuiría, a través de la composición de los lugares, los ritmos y las voces, a potenciar su incertidumbre poética.

\footnotetext{
21 Georges Didi-huberman, Pueblos expuestos, pueblos figurantes, Buenos Aires, Manantial, 2014 [2012], p. 221.

22 Marco Antonio BAzzocchi, L'Italia vista dalla luna. Un paese in divenire tra letteratura e cinema, Milán, Bruno Mondadori, 2012, p. 50.

23 Este es el concepto que daría título a otras ficciones documentales posteriores de Pasolini, como los Appunti -de los que hablaré más abajo-, así como a las diferentes secciones que componían el proyecto Petrolio (publicado póstumamente en 1992).

24 Patrick Boucheron, Conjurer la peur. Essai sur la force politique des images, París, Éditions du Seuil, 2013, pp. 71-96.
} 
En lo relativo a Dante, Pasolini recuperó su inspiración a través de la obra de Erich Auerbach. La “divina mímesis" resultante concebía el realismo como la hibridación de materiales lingüísticos, estilos y saberes de diversa índole, una heterogeneidad dialéctica llamada a generar un exceso poético que habilitara la irrupción de lo real en el terreno de lo simbólico ${ }^{25}$. Desde esa mirada, Pasolini convocaba el pathos del realismo expresionista que identificaba en la obra de Guttuso, cuyas imágenes (La crocifissione ${ }^{26}$, de 1942, o la serie Gott mit uns, de 1945, centrada en la experiencia concentracionaria del nazismo) aparecen en la película -de modo bastante injusto e impreciso- como la antítesis del vanguardismo informalista de Jean Fautrier. El gusto por la hibridación explica también la crítica de Pasolini al estructuralismo, cuyo desprecio por la historia provendría de ver en esta un cúmulo de impurezas y de confusión.

Finalmente, esa hibridación realista era compatible con un naturalismo que se remitía a los estudios del historiador del arte Roberto Longhi, a cuyas clases en la Universidad de Bolonia Pasolini había asistido a finales de los años treinta: el cineasta situaba en su memoria ese curso en los años 1938-39 o 1939-1940, es decir, en el período de irrupción de la Segunda guerra mundial. Pasolini recuperaría en su pensar fílmico la aproximación de Longhi a las imágenes caravaggiescas como "fotogramas". Longhi empleaba este término en su sentido etimológico: la luz fulminante hacía aparecer la realidad a través del "uso pictórico (léase poético) de una "cámara oscura"" (Caravaggio manejó esta tras recurrir en una fase anterior al uso de espejos) de tal modo que lo natural y lo mágico coincidían en el "instante de crónica"27. Longhi relacionaba este uso de la cámara oscura en Caravaggio con el conocimiento del libro de Giambattista Porta Magia naturalis, aparecido en dos ediciones en 1558 y 1589. Fue el historiador del arte italiano quien alumbró en Pasolini la facultad de contemplar la obra de Caravaggio como la invención de un lenguaje "profílmico" capaz de captar "todo lo que está delante de la cámara (...): nuevos tipos de personas, en sentido social y caracteriológico, nuevos tipos de objetos, nuevos tipos de paisaje"28.

Esta democracia visual del naturalismo caravaggiesco se articularía en Pasolini con una aportación del pintor italiano de signo aparentemente adverso o, tal vez, solo complementario: el "diafragma luminoso" que concedería a sus figuras un aspecto distante y artificial, "como reflejadas en un espejo cósmico" ${ }^{29}$. Esa luz transmutaría "los rasgos populares y realistas" en una "caracteriología mortuoria", que enlaza con el segundo sentido político que adquiere la alegoría en La rabbia pasoliniana. Cuando Pasolini invoca el pianto como una suerte de herencia mesiánica del proletariado (un pasaje de la película alude a le loro ereditarie lacrime, "sus lágrimas hereditarias"), esboza una presencia de la muerte común a la delineada por Benjamin en torno al drama barroco alemán (Trauerspiel). El film puede interpretarse, desde esta pers-

\footnotetext{
25 Pier Paolo Pasolini, La Divina Mímesis, Buenos Aires, El Cuenco de Plata, 2011. Emanuela Patti exploró el impacto de la lectura de la obra de Dante planteada por Auerbach en la producción literaria y cinematográfica de Pasolini. En la interpretación del crítico literario alemán, Dante aproximaba la alta y la baja cultura mediante un realismo híbrido que integraba diversos estilos y voces. Esto permitía prolongar el proyecto neorrealista bajo nuevos parámetros, al concentrar la pluralidad de discursos dialectales y las marcas performativas de la autoría pasoliniana. Ese modelo de realismo dantesco entraría en crisis con el transcurso de los años sesenta, lo cual explicaría el componente post-realista del último período de la obra pasoliniana, $c f$. Emanuela PATTI, Mimesis. Figure di realismo et postrealismo dantesco nell'opera di Pier Paolo Pasolini, Birmingham, University of Birmingham, 2008.

${ }^{26}$ El pathos trágico de la crucifixión y la deposición aparecen como motivos recurrentes en la obra de Pasolini, asociados a la subproletarización de la imagen de Cristo (La ricotta, 1963) o a la evocación de la mater dolorosa (en el eje que atraviesa su obra desde Mamma Roma, de 1962 a El evangelio según San Mateo, de 1964, donde es su propia madre quien interpreta el papel de la Virgen María). El imaginario religioso al que se remontaba el cineasta italiano abarcaba desde la alta pintura manierista y barroca (Rosso Fiorentino, Pontormo, Caravaggio) a la expresividad de la ritualidad popular en las culturas del mezzogiorno, objeto de atención de los trabajos de De Martino durante los años cincuenta.

27 "En Caravaggio (...) es la realidad misma la que sobreviene de la luz (o de la sombra) por 'incidencia'; el incidente de luz y sombra deviene causa eficiente de la nueva pintura (o poesía) (...) En efecto, el artista recortó esta descripción de luz, este poético 'fotogramma', cuando el instante de crónica le parece emerger”, Roberto LongHi, Caravaggio, Milán, Abscondita, 2013, [1952], pp. 42-43. La traducción es mía.

28 Pier Paolo PAsolini, "La luz de Caravaggio" [en línea], http://www.circulobellasartes.com/mediateca/luz-caravaggio/ [Consulta: 2 de abril de 2017].

29 Ibidem.
} 
pectiva, como una alegoría del cuerpo mártir del proletariado, cuya llamada a través del lamento lo rescata para la comunidad presente y futura de los condenados de la tierra. Este internacionalismo del pianto aglutinaba en una imagen múltiple y común diferentes tiempos y geografías (desde Corea a Cuba, pasando por Hungría), asociando "los días del llanto" a la experiencia de la migración y la muerte ${ }^{30}$. La versión en la textura granulada del blanco y negro fílmico de la impronta mortuoria de la luz caravaggiesca se conjuga en La rabbia con la alusión a un episodio de la Divina Comedia, en el que el condottiero Buonconte da Montefeltro es salvado por el ángel gracias a la lágrima que sale de sus ojos mientras muere. Para completar la cadena de significantes, esa poética luctuosa se extendía a la comprensión del propio lenguaje cinematográfico. El cine aparecería en la teorización pasoliniana posterior como un medio sobreviviente, "una vida después de la muerte" inscrita en la dialéctica de la historia:

No bien [alguien] está muerto, (...) se realiza una rápida síntesis de su vida apenas conclusa. Caen en la nada millones de actos, expresiones, sonidos, voces, palabras, y sobreviven algunas decenas o centenares. Un número enorme de frases que ha dicho en todas las mañanas, los mediodías, las tardes y las noches de su vida, caen en un abismo infinito y silencioso. Pero algunas de estas frases resisten, casi milagrosamente, se inscriben en la memoria como epígrafes, quedan suspendidas en la luz de una mañana, en la tenue oscuridad de una noche: la mujer o los amigos, al recordarlas, lloran. En un filme estas son las frases que quedan ${ }^{31}$.

Los textos teóricos de Pasolini se interesaron por explorar los terrenos de la semiótica más allá de la vertiente significante del lenguaje literario. En su concepción del cinematógrafo como el medio técnico cuyo código se identificaba con el de la realidad, Pasolini veía en el cine de poesía, por contraposición a la semiótica del cine de prosa, una vía de acceso al universo onírico de la memoria y a las sensaciones que el ser humano experimenta de la realidad de modo previo a su acceso al logos. Los lenguajes literarios encontraban así su contrapunto en un código que, sin embargo, no se declaraba como asignificante. Este código presentaría dos peculiaridades: en primer lugar, a diferencia de los asertos surrealistas, no se hallaría por encima de la realidad, sino que reproduciría nuestra experiencia del mundo en un sentido antropológico. Por otra parte, pese a los puntos en común resaltados más arriba, Pasolini se distanciaba en algunos aspectos de la concepción de la técnica en Benjamin. Para el cineasta italiano, el cinematógrafo no modificaría históricamente, tal y como había sugerido Benjamin, nuestra percepción de la realidad, sino que desdoblaría ante nuestros ojos el lenguaje pregramatical de la misma. En segundo lugar, ese código se hallaría condicionado por una suerte de "simpatía por el caos". A diferencia del escritor literario, el autor cinematográfico no extraería sus signos de un dispositivo estructurado de la langue como el diccionario, sino del conjunto de las cosas del mundo ${ }^{32}$. En su polémica con Christian Metz, Pasolini señalaba que más que identificar al lenguaje cinematográfico con una "impresión de realidad", cabía hablar de este como "realidad tout court". El cinematógrafo habría anticipado la ambición fenomenológica del método de Edmund Husserl por concretar una filosofía que fuera "a las cosas mismas". Este lenguaje de la aparición tendría por unidad mínima "los diversos objetos reales que componen un encuadre" y se constituiría como un Ur-Código no-verbal, que las diversas lenguas traducirían en signos que, en su afán comunicativo, verterían una capa de olvido sobre aquel primer lenguaje de la praxis vital ${ }^{33}$. Los gestos subalternos de $L a r a b$ bia vendrían a recuperar esa experiencia perdida del origen.

30 Sobre el pasaje de la película en que se suceden imágenes correspondientes a la población húngara que huía tras el asedio de las tropas soviéticas en 1956, la voz de Bassani lee los siguientes versos: "Estas nieves eran del año pasado, o de hace mil años, antes de toda esperanza. ¿Dónde las hemos conocido, estas nieves, estas nieves que enmarcaron los días del llanto? Son nuestras madres, hijas, sobrinos, nuestros viejos parientes, estas figuras idénticas, sobrevividas de los días del llanto -que lloran-. El 43, el 44, ¡son ellos los años de esta blancura, de esta emigración! No habían transcurrido, estaban aquí, con sus nieves indelebles, con sus lágrimas heredadas". La traducción es mía.

31 "El miedo al naturalismo", texto escrito por Pasolini en 1967, contenido en PASOLINI, 2005, pp. 335-337.

32 PAsolini, 2005, pp. 233-239.

33 Ibidem, p. 277-278. 
En su comprensión micropolítica de la construcción de la hegemonía, Gramsci insistía en que esta aparece como un "proceso molecular" y "capilar" que va permeando la subjetividad de las clases populares hasta constituir un bloque histórico ${ }^{34}$. Pasolini, en su intento de convertirse en un cineasta nacional-popular, exploró esa idea en La rabbia a través de una imagen de la subalternidad que, en el lamento, permanecía investida de esperanza. Esa fe tendió a diluirse con el tiempo, como se puede apreciar en las invectivas de crítica social y política que realizara hacia el final de su vida. En ellas, Pasolini denunció el "genocidio cultural" que las sociedades de consumo masivo perpetraban al erradicar la conciencia y la identidad resistentes del subproletariado romano bajo la forma de un proceso de homogeneización subjetiva. África se convertiría entonces en el único reducto posible de resistencia y singularidad. Esta constatación iría acompañada de un giro del gesto a la voz: ya no era suficiente con superponer las entonaciones narrativas y poéticas sobre la gestualidad subalterna, sino que esta debía expresar su propia visión del mundo. Así sucede en películas como Appunti per un film sull'India (1968) y Apuntti per un'Orestiade africana (1970). En la primera, ese tránsito se produce a través de las entrevistas captadas en sonido directo con diversos sujetos de la sociedad India (obreros, campesinos, políticos e intelectuales), que deshacen la uniformidad retórica del concepto de pueblo en La rabbia. En la Orestiada africana, al trasladar la tragedia de Esquilo al contexto poscolonial, Pasolini se interesó por contrastar su visión de ese proceso histórico con la de un grupo de estudiantes africanos radicados en Roma. Mediante el discurso indirecto libre, ya ensayado en el campo de la novela (Ragazzi di vita, 1955), el cineasta italiano lograba que la voz de esos estudiantes resonara en conflicto con la suya propia: por ejemplo, en un momento concreto de la película, uno de los estudiantes le reprocha lo abusivo que resulta hablar de "África como un todo". De este modo, se desdoblaba en dos sujetos reales el diálogo repleto de sinergias y fricciones que en La rabbia asumían la voz poética de Bassani, la voz narrativa de Guttuso y la voz autoritaria que Pasolini identificaba con el formato del informativo televisivo.

La representación del sujeto subalterno en la obra de Pasolini se halla vinculada a una redefinición del documental que, en el decurso de los sesenta, daría lugar a lo que denominó como una "semiótica de lo real" ${ }^{35}$. Así sucede en obras como los cuadernos de viaje Sopralluoghi in Palestina (1963-1964) -que escribió durante un viaje a Oriente Próximo con el objetivo de preparar el rodaje de Il Vangelo secondo Mateo (1964) - y en los dos filmes compuestos de "appunti”. Según ha destacado Fernando González García, los "appunti" permitieron a Pasolini profundizar en la afinidad entre cine y poesía que perseguía su proyecto fílmico, enfatizando una dimensión polifónica (construida a través de la relación entre imagen y sonido) que desplegaría los recursos ya empleados en La rabbia. Tal poetización del cine entrañaba una simpatía por el proletariado internacional que le conduciría a elucubrar una película titulada Appunti per un poema sul Terzo Mondo, nunca realizada ${ }^{36}$. Aunque González García identifica la aparición de esa forma de escritura en el rodaje sobre la India, coincide con la interpretación que aquí propongo en subrayar las líneas de continuidad que presenta con el ensayo visual-textual diagramado por La rabbia, donde se dibujaba una comunidad política del Sur entre la Resistencia europea y las luchas de liberación en el Tercer Mundo, entre "morir en Nápoles, Sevilla o Cuba"37.

34 Antonio Gramsci, Cuadernos de la cárcel, Tomo III, México D. F., Era, 1981 [1948], p. 314.

35 Por apuntar los nexos entre la obra pasoliniana y los estudios poscoloniales, el intelectual palestino Edward Said, vinculado al Grupo de Estudios Subalternos, reconoció en el prefacio a la reedición de 1985 de su libro Orientalismos la influencia del cineasta italiano, interesado por la marginalidad étnico-cultural de la subalternidad. A propósito de la construcción de la subjetividad en las películas de Pasolini dedicadas al Tercer Mundo, Laura Rascaroli ha hablado de una mirada que califica como "orientalismo herético", cf. Laura Rascaroli, The personal camera. Subjective cinema and the essay film, Londres, Wallflower Press, 2009,153 y ss.

${ }^{36}$ Fernando González García, Pier Paolo Pasolini. Los Apuntes como forma poética, Santander, Shangrila, 2015, p. 9. Este mismo autor sintetiza el sentido que los apuntes adquieren en la comprensión semiótica del cine pasoliniano: "Los apuntes cinematográficos (...) están elaborados como obras a la vez acabadas y como obras que se refieren a algo por hacer. Requieren del destinatario un tipo de colaboración intensa, porque en en ellos se produce una fuerte tensión entre dos sistemas de signos distintos: palabras e imágenes (...); lo que se ve, son imágenes tomadas de la realidad, imágenes que, a pesar de amalgamarse con [el] discurso, pertenecen a esa otra lengua irreductible que es la de la realidad y de las que la palabra no se puede apropiar del todo", ibidem, p. 17.

37 Ibidem, pp. 26 y ss. 


\section{Antropología, culturas campesinas y utopía}

En su libro L'Italia vista dalla luna. Un paese in divenire tra letteratura e cinema (2012), Marco Antonio Bazzochi ha reconstruido un itinerario sensible de la cuestión del mezzogiorno durante el siglo XX italiano $^{38}$. Este horizonte de significado es esencial para comprender la relectura en clave contemporánea que Pasolini realizaba en La rabbia de los referentes clásicos de la cultura transalpina. Bazzochi sitúa como punto de fuga de la relación entre la intelectualidad italiana del siglo XX y las culturas populares del sur de la península, el libro de Carlo Levi Cristo si é fermato a Éboli, escrito entre 1943 y 1945. Debido a sus actividades antifascistas, Levi había sido desterrado por el régimen de Benito Mussolini en la región de Lucania (actual Basilicata) entre 1935 y 1936. Allí, el médico quedó impactado por el atraso que afectaba a la zona, implicándose entre otras labores en la contención de una epidemia de malaria. En los años cuarenta, la parada del Cristo literario de Levi describiría el umbral de acceso al espacio cultural de una civilización campesina que se asimilaba (en consonancia con Gramsci) al reverso de la razón progresiva. En sus recuerdos, aquella aparecía como detentora de un saber antiguo y de una ritualidad destinada a procesar el dolor, pero permanecía en los márgenes de la Historia.

Esta mirada ahistórica sobre la realidad etnológica del sur de Italia sería cuestionada en los años cincuenta por De Martino, quien -como vimos- ya había lanzado sus dardos contra esa misma tendencia en la antropología funcionalista. En Morte e pianto rituale nel mondo antico (1958), De Martino plantearía una interpretación opuesta de esa realidad -que había explorado en su trabajo de campo durante el transcurso de la década-, avizorando en ella una forma de racionalidad alternativa ${ }^{39}$. Los rituales lucanos revelarían un trato con la angustia cuya dimensión arcaica se oponía a la angustia existencialista burguesa, tantas veces (auto)parodiada por Pasolini. La magia del pianto afloraba entonces como un modo de procesar la "crisis de la presencia" derivada de la ausencia de los seres queridos, un acervo de gestos y expresiones cuya relación de sobrevivencia con el mundo antiguo era enunciada por De Martino desde el mismo título. Esa magia popular se contraponía de modo indirecto al carácter mágico-abstracto del fetichismo de mercancía, que conforma la ansiedad vital en las sociedades capitalistas contemporáneas, al recuperar de manera funcional al sistema de acumulación basado en la forma-valor esa estructura antropológica de la subjetividad.

Este tema se encontraba a su vez entrelazado con los "apocalipsis culturales", que centraron la investigación que De Martino dejó inconclusa a su muerte en 1965. El antropólogo napolitano comenzó ese proyecto por los mismos años en que Pasolini afrontó su documental sobre La rabbia. En la película, la idea del apocalipsis aparece vinculada a la amenaza de la bomba nuclear y al fulgor ingenuo y voluptuoso de Marilyn que, a modo de anuncio del comienzo de la dopostoria, se contraponía a la angustia pequeñoburguesa. Uno de los capítulos que De Martino había comenzado a delinear en su estudio se centraba justamente en la idea de los apocalipsis marxianos y pretendía indagar en lo mítico y lo dramático de ese topos revolucionario del materialismo histórico ${ }^{40}$. Pasolini, por su parte, pensaba que en la práctica la inocencia no era adecuada para afrontar los dilemas trágicos de la historia contemporánea: su concepto de abgiogia, la alegría primigenia que habita en el corazón de la angustia, trató de sintetizar ambas pulsiones. Los dos intelectuales se conocieron personalmente en agosto de 1958 durante la ceremonia de entrega del Premio Viareggio, que De Martino ganó en la categoría de ensayo por Morte e pianto rituale nel mondo antico. El año anterior Pasolini se había hecho con el mismo galardón en la categoría de poesía (ex aequo con Sandro Penna y Alberto Mondadori) por Le cenere di Gramsci.

\footnotetext{
38 BAzzochi, 2012, pp. 1-81.

39 Ernesto DE MARTINo, Morte e pianto rituale nel mondo antico. Del lamento funebre antico al pianto di Maria, Turín, Bollati Boringhieri, 2008 [1958].

40 Ernesto de Martino, La fine del mondo. Contributo all'analisi delle apocalissi culturali, Turín, Einaudi, 2002 [1977], pp. 415-462.
} 
Un año después Pasolini colaboraría con la escritura de un poema en la realización del documental de Cecilia Mangini titulado Stendali (Suonano ancora) ("Suenan todavía", de 195941), que ya desde el propio título anunciaba la pregnancia de lo superviviente, inspirada en las teorías de De Martino sobre el mundo antiguo y el pianto rituale en el Sur de Italia. La película es un hito cronológico y conceptual entre esos hallazgos etnográficos y la poética-política de La rabbia. Mangini, directora de la Puglia (Apulia, región en el extremo sureste de la península itálica), eligió en este caso un pueblo del Salento para localizar la pervivencia de esos rasgos de la antigüedad en los rituales fúnebres de la cultura popular. El texto que precedía los registros del pianto redundaba en las ideas que he enunciado anteriormente, remarcando además que las voces que oímos lloran al muerto en griego:

Alguien ha muerto. Lo anuncia el sonido de las campanas. Las vecinas vienen a consolar a las madres, a las esposas o a las hermanas, y lloran con ellas. Es la visita fúnebre. Después serán solo los hombres quienes acompañen al féretro al cementerio. Mientras tanto las mujeres, en la casa, continúan el llanto. El llanto, así regulado y ritualizado, es una supervivencia arcaica de una sociedad que de hecho es de diversos modos arcaica: la sociedad de las áreas deprimidas, esto es, de casi toda la Italia meridional. En una sociedad similar, llena de condiciones económicas a veces inhumanas, la muerte sería intolerable, privada de sentido, si su dolor disgregador no fuese contenido por la institución prosaica del llanto, por el cual las manifestaciones desesperadas de la vitalidad vienen a ser, por decirlo así, estilizadas. Algunos cantos fúnebres, como por ejemplo estos de los pueblos de la Puglia de lengua griega, se encuentran entre las formas más elevadas de la cultura popular.

A continuación, sobre la secuencia de imágenes del pianto ritual, una voz femenina cantaba con desgarro el poema de Pasolini:

Llorad, madres que tenéis hijos/ llorad con todo vuestro dolor/ que os lleguen las hojas del alma/ que os ha abandonado antes de tiempo/ Viene la muerte que no nos respeta/ que nos ha señalado a todos/ Llorad el luto, todos vosotros chiquillos/ llorad grandes, llorad muchachos/ esta flor ha perdido toda fuerza/ y tenía apenas dieciséis años/ Yo te esperaré, oh mi hijito/ yo te esperaré hasta las tres/ y cuando vea que no vienes/ correré a buscarte al huerto y al patio/ Yo te esperaré, yo, mi hijito/ Yo te esperaré hasta las cinco/ y cuando vea que no vienes/ correré a buscarte a casa de todos los parientes/ Yo te esperaré, yo, mi hijito/ yo te esperaré hasta las nueve/ y cuando vea que no vienes/ perderé toda esperanza/ y si veo que no vienes/y a las diez no te haces ver/ a las diez habré devenido tierra/ tierra, tierra para sembrar/Yo te esperaré, oh mi hijito/ yo te esperaré hasta final del año/ y cuando vea que no vienes/ me chamuscaré como hollín/ Y tú, corazón quemado, llora, llora/ grita siempre como un buey salvaje/ que en el mundo ha perdido toda luz/ Me lo hubieses dicho, hijo mío/ que estabas por partir/ Te habría preparado una cesta/ con toda tu ropa/¿Quién te preparará el vestido/ cuando llegue el domingo?/ Ninguno de todos los que aquí están/ Tú restarás solo/ ¿Quién te lavará la camisa, hijo mío?/ Te la lavarán la lápida y la tierra/ ¿Y quién te la podrá planchar?/ Te la plancharán la lápida y la tierra/¿Quién te despertará, hijo mío,/ cuando el día esté en lo alto?/ Allá abajo es siempre sueño/ siempre noche oscura.

Tanto en Suonano ancora como en La rabbia, el canto fúnebre (thrènos) aparece como una ex-posición de la pena en tanto afecto común (aquella fuerza que atraviesa nuestros cuerpos sin poder apropiárnosla), que al tiempo que procesa el duelo redefine los vínculos de una nueva comunidad proletaria. Al fin y al cabo, el gesto y la voz que en él confluyen encarnan aquellas expresiones que, siéndonos más propias (más singulares), menos nos pertenecen -hasta el punto de que es frecuente que no nos reconozcamos en ellas. Este comunismo de lo sensible se topa hoy con los límites que el "genocidio cultural" practicado por el neocapitalismo impone a la posibilidad de irrupción de ese pasado arcaico en el presente bajo una forma liberada de atavismos culturales y jerarquías sociales ${ }^{42}$. ¿Cabe desde esta posición imagi-

41 El documental puede visualizarse en este enlace: https://www.youtube.com/watch?v=Ox01TQprvdM [Consulta: 2 de abril de 2017]. Las traducciones de los dos textos que siguen son mías. 
nar que la feminización del duelo y del trabajo de los cuidados, deslizada por las palabras del poema pasoliniano en Suonano ancora, pueda ponerse en valor hoy como una estructura de socialización que, a su vez, lamine la división sexual del trabajo? ¿Pueden duelo y cuidados cuestionar las bases ideológicas que asocian los derechos y el reconocimiento social a la integración en las relaciones de producción capitalistas? ¿Qué progreso situaría en la actualidad en punto crítico el pianto como política del Sur, cuando la historia parece haberse vaciado de la fe colectiva en el destino luminoso de la humanidad? ¿Qué subalternidad convocaría?

Quizás la respuesta parcial se halle tan lejana en nuestro imaginario colectivo como próxima cronológicamente, si atendemos tanto al pasado generacional que muchas de nosotras compartimos como a los retos materiales, políticos y culturales que la crisis ecosocial (con el colapso energético derivado del agotamiento de los combustibles fósiles y las repercusiones del cambio climático) dibuja en el inmediato porvenir. Es probable que más pronto que tarde debamos recuperar por fuerza algunos elementos de la memoria vital de las culturas campesinas, predominantes en la subalternidad global no alineada (y no alienada) compuesta por $L a$ rabbia. En una carta abierta dirigida al escritor Italo Calvino en 1974, Pasolini (2009) explicaba:

El universo campesino -al que pertenecen las culturas subproletarias urbanas $\mathrm{y}$, hasta hace pocos años, las de las minorías obreras (...)- es un universo transnacional, que incluso no reconoce las naciones. Es el resto de una civilización anterior (...) Este ilimitado mundo campesino prenacional y preindustrial, que sobrevivió hasta hace unos años, es lo que añoro - no en vano paso todo el tiempo que puedo en países del Tercer Mundo, donde aún sobrevive, aunque el Tercer Mundo también está entrando en la órbita del llamado Desarrollo- (...) He dicho, y lo repito, que la aculturación del Centro Consumista ha destruido las culturas del Tercer Mundo muy semejantes a las culturas campesinas italianas: el modelo cultural que se ofrece a los italianos $-\mathrm{y}$ a todos los hombres del planeta- es único ${ }^{43}$.

Como señaló John Berger, en ese universo campesino los tiempos cíclicos siempre predominaron sobre la concepción lineal de la historia y estuvieron asociados a una concepción de la vida como sobrevivencia que nos puede ser de utilidad práctica ${ }^{44}$. El imaginario pasoliniano tendió a establecer una simbiosis entre naturaleza y pueblo que hundía sus raíces míticas en una "culturalización de la naturaleza" que hacía "de todo lo viviente un hablar" 45 . En 2006 Berger subrayaba el don profético de Pasolini. La rabbia representaba para él "un mensaje providencial que (...) es arrastrado a nuestra playa dentro de una botella". Este mensaje estaría cargado de un amor-luz (Simone Weil dixit) inquebrantable por la realidad, surgido de una "decepción histórica demasiado profunda" en la que el adagio entonado por el "coro griego" -la música de Albinoni como bajo continuo del filme, las voces en contrapunto de Guttuso y Bassani- aglutinaba las esperanzas del comunismo vencidas por la industria cultural y la desaparición del "último campesino". Esas voces compondrían en el presente una cita entre generaciones, donde el recuerdo del mundo antiguo se sustraía al cálculo del futuro. A Berger le resultaba fascinante que "¡en otro momento [Pasolini] nos propone a todos que soñemos con el derecho a ser como eran algunos de nuestros antepasados!". El ángel de Pasolini evocado por el crítico inglés rememoraba el ángel de la historia benjaminiano, su aparición bajo la forma de la justicia divina:

42 El propio Pasolini, tras afirmar que la revolución salva al pasado, nos recordaba en la secuencia de La rabbia dedicada a Marylin Monroe el "espanto" de un mundo preindustrial sumido en la dureza de las tareas agrícolas y en la superstición religiosa.

43 Pier Paolo Pasolini, Escritos corsarios, Madrid, Ediciones del Oriente y del Mediterráneo, 2009, pp. 66-67.

44 John Berger, Puerca tierra, Madrid, Suma de Letras, 2001, pp. 329-363.

45 Pasolini contraponía esa "culturalización de la naturaleza" a la "naturalización de la cultura" de la que le acusó Umberto Eco, cf. PAsolini, 2005, pp. 373-382. El panteísmo pasoliniano asoma con especial fuerza en las secuencias iniciales de Medea (1969), con el diálogo entre Jasón y el Centauro, en el que se establece una suerte de secuencia poética entre el animismo, la agricultura y la modernidad: "No hay nada de natural en la naturaleza (...) Cuando la naturaleza te parezca natural, todo habrá acabado y comenzará algo distinto". 
La película sólo dura una hora, una hora ideada, medida y editada hace cuarenta años. Y contrasta tanto con los noticiarios que vemos y con la información que nos ceban en la actualidad que, al terminar la hora, te dices que hoy en día no sólo están desapareciendo y extinguiéndose especies animales y vegetales, sino prioridades humanas que, una tras otra, están siendo sistemáticamente rociadas, no de pesticidas, sino de eticidas: agentes que matan la ética y, por consiguiente, cualquier idea de historia y de justicia ${ }^{46}$.

En contraste con los medios masivos, Silvestra Mariniello estima que el principal hallazgo de La rabbia consistía en "producir un nuevo espacio-tiempo audiovisual", que a la vez que rescataba poéticamente la gestualidad popular exploraba las posibilidades alternativas de esos medios. Aunando mundos, Pasolini asumía que "linealidad, verdad y progreso ya no son conceptos operativos", o al menos no lo son dentro de las coordenadas de la Historia burguesa ${ }^{47}$. El insospechado retorno de la cosmovisión ética a la que aludía Berger tal vez acabe por disolver la distinción clásica entre bios (vida política) y zoè (nuda vida), propia de comunidades sostenidas en una relativa abundancia material y en la división social y sexual del trabajo. Si la sobrevivencia atravesó de manera fulminante la imaginación política de La rabbia, estamos a la espera (tal vez tan solo en los albores de la esperanza) de que los pueblos resultantes de la exclusión neoliberal se doten de una forma política de sobrevivencia, de una vida en común que desactive los dispositivos biopolíticos de la modernidad.

Las afirmaciones anteriores entrañan una dimensión utópica. En última instancia, La rabbia era una visión apocalíptica de la Historia (el hongo nuclear como colapso de la tecnociencia de la guerra capitalista) que la dopostoria convertiría en prehistoria. La película deshacía en este plano el bloqueo de la imaginación utópica característico del antiutopismo de la Guerra fría, en el que aquella quedaba asociada con los demonios totalitarios del estalinismo. Al margen de ese elemento ideológico, la consolidación del poder soberano de la mano de la implantación y generalización de la industria cultural y las sociedades del espectáculo (el hilo rojo que une a Theodor W. Adorno, Guy Debord y al propio Agamben) en la posguerra anticipaba el modo en que el capitalismo tardío sofocaría las formas utópicas del deseo, la posibilidad de desdoblar el mundo (este es, al fin, el poder de la ficción) contra el "there is no alternative" tatcheriano.

Aunque Pasolini no renunciara a reavivar los rescoldos desarrollistas de la utopía soviética (la patria de la clase obrera), no resulta aleatorio que el pathos trágico de sociedades de base campesina (ese proletariado apátrida) fuera el elemento nuclear en las imágenes de la subalternidad global de La rabbia. Fredric Jameson resaltó el modo en que el origen de la utopía moderna en la obra de Tomas Moro se vinculaba a su disidencia crítica respecto a la política de cercamiento de los terrenos comunales auspiciada por Enrique VIII, que acabó también con la forma de vida monástica. El propio Marx volvería sobre este aspecto del reinado del monarca -así como sobre la jurisdicción contra el vagabundeo y la pobreza- en el capítulo del primer volumen de El capital (1863) dedicado a la acumulación originaria. Jameson subraya que la función de la utopía es instalar "un enclave imaginario dentro del espacio social" que, con frecuencia, adopta "la formación momentánea de una especie de remolino" - de nuevo la estructura del origen invocada por Benjamin y el Petrolio pasoliniano-48. En el caso de la imaginación campesina, ese remolino utópico adquiría una dimensión alegórica ideal que aludía al carácter cíclico de las estaciones, a una cultura propia que (a diferencia de la clase obrera) no debía ser inducida desde el exterior, a un biomimético y armónico respeto de los ritmos naturales y, en fin, "al recuerdo de la tierra y la aldea, este vestigio a medias olvidado de la experiencia de la solidaridad y la colectividad campesinas"49.

46 John Berger, "El coro que llevamos en la cabeza", [en línea], https://elpais.com/diario/2006/08/26/babelia/1156549152_850215.html, [Consulta: 3 de junio de 2018].

47 Silvestra Mariniello, Pier Paolo Pasolini, Madrid, Cátedra, 1999, p. 213, citado en González García, 2015 , p. 34.

48 Fredric Jameson, Arqueologías del futuro. El deseo llamado utopía y otras aproximaciones a la ciencia ficción, Madrid, Akal, 2009 [2005], p. 31.

49 Ibidem, p. 114. 
La actualización de ese imaginario en clave ecosocial y postcapitalista solo puede tener sentido si no se pliega ni al deseo de fuga hacia "lo natural" de las clases medias urbanas, ni a las versiones idealizadas de la vida rural o preindustrial. Se trataría de avanzar tanto en una crítica radical de las formas de explotación asociadas a las relaciones de producción -que en el origen del capitalismo industrial actuaron como un dispositivo concentracionario de la población campesina- y de exclusión social como en una cierta reinvención onírica del mundo que no sea funcional ni al irracionalismo arcaico ni al fetichismo de la mercancía. Benjamin y Pasolini sabían que en el umbral de la emancipación materialismo y magia tienden a coincidir. Una forma utópica de sobrevivencia exige imaginar una articulación libidinal no productivista de la vida social. Eso pasa por politizar el malestar derivado de lo que Mark Fisher ha denominado la "hedonia depresiva" de las sociedades tardocapitalistas, asociada a la confluencia del hiperconsumo, el mandato de goce y la saturación de estímulos informacionales ${ }^{50}$. En su lugar, se trataría de reivindicar una askesis ${ }^{51}$ de clase y descolonizadora que intensifique (y no niegue) el deseo. Si la cultura campesina siempre fue una cultura de subsistencia (una cultura del cultivo), es probable que la sociedad emancipada del futuro deba pensarse -en la línea de lo sugerido en una ocasión por Adorno- no tanto como una realización de las potencias humanas o de la voluptuosidad material, sino como una comunidad en la que nadie sufra hambre y donde el lujo posea una cualidad relacional. Nuestra especie ha de pasar a ser una especie entre otras, que vuelva a observar (más que a contemplar) los mirabilia del mundo como si en ello le fuera la vida.

JAIME VINDEL GAMONAL es investigador posdoctoral del programa Ayudas Juan de la Cierva - Incorporación 2015 (MICINN) en la Sección departamental de Historia del Arte III (Contemporáneo) de la UCM y miembro del Claustro de profesores del Programa de Estudios Independientes del Museo de Arte Contemporáneo de Barcelona. Doctor europeo en Historia del Arte y Magíster en Filosofía y Ciencias Sociales. Durante los últimos años ha desarrollado su trabajo en universidades de Argentina, Chile y España. Entre otros centros de I+D, ha sido investigador visitante en el Museo de Arte Moderno de Nueva York, la Universidad de las Artes de Londres y el Instituto de Investigaciones Estéticas de la Universidad Nacional Autónoma de México. Integró el equipo curatorial de la exposición "Perder la forma humana. Una imagen sísmica de los años ochenta en América Latina", inaugurada en el Museo Nacional Centro de Arte Reina Sofía en octubre de 2012, cuyo catálogo coeditó. Es autor de numerosos ensayos publicados en revistas y obras colectivas, así como de libros escritos en solitario o colectivamente. Recientemente ha editado el volumen Visualidades críticas y ecologías culturales (Madrid, Brumaria, 2018). Es miembro de la Red Conceptualismos del Sur, una plataforma de investigación sobre las prácticas artístico-políticas emergidas en América Latina desde la década de los sesenta.

Email: javindel@ucm.es

50 Mark FISHER, Realismo capitalista. ¿No hay alternativa?, Buenos Aires, Caja Negra, 2016 [2009], p. 120.

51 Como recordó Erri de Luca en torno a la experiencia de la escalada, "escalar solo es askesis, que traducimos como ascesis, pero que en griego no tenía nada de espiritual, era, por el contrario, ejercicio, práctica. Es gratis, con esas gotas de gracia que uno busca en sus propios actos", Erri De Luca, Tras la huella de Nives. En el Himalaya con una alpinista, Madrid, Siruela, 2006 [2005], p. 81. 
